\title{
Ligninolytic Enzymes Produced by Gliomastix sp. in an Organic Waste Medium
}

\author{
Nengah Dwianita Kuswytasari ${ }^{1}$, Maya Shovitri ${ }^{1}$, and Enny Zulaika ${ }^{1}$
}

\begin{abstract}
Ligninolytic enzymes are extracelluler enzymes for cutting lignin or lignocelluloses, a complex carbohydrate, to be a more simple carbohydrate. The enzymes have a commercial value for many kinds of industrial purposes, ex. pulp and paper industry. Gliomastix sp. was one reported fungi that produced those enzymes. Since organic waste was a cheap and potential organic source for microbial growth, this study was aimed to figure out whether Gliomastix sp. T3.7 able to produce ligninolytic enzyme on several chosen organic waste medium, and to detect the effect of temperature and pH on its enzymatic activity. The enzymatic activity was measured using spectrofotometer UV-Vis. The result showed that Gliomastix sp. T3.7 was able to produce laccase, manganese peroxidase (MnP) and lignin peroxidase (LiP) that belonged to ligninolytic enzymes. Each enzyme showed a different need of temperature and pH condition for each particular optimum activity. On a sugarcane baggase waste medium, Gliomastix sp. T3.7 reached an optimum laccase activity of $1,8 \mathrm{U} / \mathrm{ml}$ at $35^{\circ} \mathrm{C}$ and on pH 6, while MnP activity $(1 \mathrm{U} / \mathrm{ml})$ at $25^{\circ} \mathrm{C}$ and on $\mathrm{pH} 4$. The activity of $\mathrm{LiP}$ was optimum of $8,1 \mathrm{U} / \mathrm{ml}$ on a corn cobs waste medium at $35^{\circ} \mathrm{C}$ and on $\mathrm{pH} 5$.
\end{abstract}

Keywords - Gliomastix sp, organic waste medium, ligninolytic enzyme.

Abstrak-Enzim ligninolitik adalah enzim ekstraseluler untuk memotong lignin atau lignoselulosa, karbohidrat kompleks, menjadi karbohidrat yang lebih sederhana. Enzim memiliki nilai komersial untuk berbagai jenis keperluan industri, ex. industri pulp dan kertas. Gliomastix sp. adalah salah satu melaporkan jamur yang menghasilkan enzim yang. Sejak sampah organik adalah sumber organik murah dan potensi pertumbuhan mikroba, penelitian ini bertujuan untuk mengetahui apakah Gliomastix sp. T3.7 mampu menghasilkan enzim ligninolitik pada beberapa media sampah organik yang dipilih, dan untuk mendeteksi pengaruh suhu dan $\mathrm{pH}$ terhadap aktivitas enzimatik nya. Aktivitas enzimatik diukur menggunakan spektrofotometer UV-Vis. Hasil penelitian menunjukkan bahwa Gliomastix sp. T3.7 mampu menghasilkan lakase, mangan peroksidase (MNP) dan lignin peroksidase (LiP) milik enzim ligninolitik. Setiap enzim menunjukkan kebutuhan yang berbeda dari suhu dan kondisi pH untuk setiap kegiatan yang optimal tertentu. Pada media limbah tebu ampas, Gliomastix sp. T3.7 mencapai aktivitas lakase optimum 1,8 U / ml pada 350C dan pH 6, sementara aktivitas MNP (1 $\mathrm{U} / \mathrm{ml}$ ) pada 250C dan pH 4. Kegiatan LIP adalah optimum 8,1 U / ml pada medium limbah tongkol jagung di 350C dan pH 5.

Kata Kunci-Metode Numerik, Campuran Konveksi, Ruang Didinginkan, Perpindahan Panas.

\section{INTRODUCTION}

L ignocelluloses are the most abundant renewable organic matter on earth and they contribute to the majority of the agroindustrial residues over the world. The utilization of lignocelluloses for ligninolytic enzyme production has been studied extensively. Production of laccase, manganese peroxidase $(\mathrm{MnP})$, and lignin peroxidase (LiP) from a wide variety of agro-industrial residues has been reported. Most of the works on ligninolytic enzyme production from agro-industrial residues deal with fungi [1].

Lignocelluloses are featured by biomass recalcitrance in nature where hemicellulose and cellulose are densely packed by layers of lignin [2]. Lignin, like cellulose and hemicelluloses, is a major component of plant materials and the most abundant form of aromatic carbon in the biosphere. As a complex aromatic macromolecule, it provides strength and rigidity to cell walls and tissues of all vascular plants by acting as a glue between the polysaccharide filaments and fibres. In addition, lignin is involved in water transport in plants and forms a barrier against microbial destruction by protecting the readily assimilable polysaccharides. From the chemical point of

${ }^{1}$ Nengah Dwianita Kuswytasari, Maya Shovitri, and Enny Zulaika are with Departement of Biology, Faculty of Mathematics and Science, Institut Teknologi Sepuluh Nopember, Surabaya, 60111, Indonesia. Email: kuswytasari@bio.its.ac.id. view, lignin is a heterogeneous, optically inactive polymer consisting of phenylpropanoid interunits, which are linked by several covalent bonds (e.g. aryl-ether, arylaryl, carbon-carbon bonds) [3-5]. The polymer arises from laccase and/or peroxidase initiated polymerization of phenolic precursors via the radical coupling of their corresponding phenoxy radicals [5-6] . Lignin cannot be degraded by hydrolytic enzymes as most other natural polymers (cellulose, starch, proteins, etc.) because of its bond types and heterogeneity.

Lignin biodegradation is fundamental to potential applications for pulp and paper industry. That why a rapid understanding of how to degrade lignin, may provide a challenge of biotechnology applications in pulp and paper manufacturer. Research continues on the lignin degrading enzyme system involved; its nature, production, mechanism of action, and molecular genetics [7-11].

The main extracellular lignin degrading enzymes are laccase, MnP, and LiP. Laccase is a copper-containing polyphenol oxidase. It catalyses the reduction of fourelectron oxygen to water and this is typically accompanied by the oxidation of a phenolic substrate to fenoxil radical. Though the laccase produced by Trametes vesicolor is able to oxidize nonphenolic substrates provided with 2,2'azinobis (3ethylbenzthiazoline-6-sulfonate). The molecular weight of laccase is between $60-80 \mathrm{kDa}$ and its isoelectric point is between 3 and 4. Manganese peroxidase is an enzyme 
containing Fe which oxidize phenol to phenoxy radicals by oxidizing $\mathrm{Mn}^{+}$to $\mathrm{Mn}^{+}$using $\mathrm{H}_{2} \mathrm{O}_{2}$ as oxidant. $\mathrm{Mn}^{+}$ was then chelated using oxalic acid or malic that spontaneous oxidize phenolic lignin. The molecular weight of $\mathrm{MnP}$ is $40-50 \mathrm{kDa}$ and the isoelectric point is between 3 to 4 though neutral MnP is also found. Lignin peroxidase could also oxidize non phenolic aromatic compound [12].

In the present study, we reported that fungi Gliomastix sp. T3.7 produced laccase, $\mathrm{LiP}$ and $\mathrm{MnP}$ on organic lignocellulosic waste (rice straw, corn cobs, sugarcane bagasse and sawdust) as medium. Each particular enzymes showed different enzymatic activity over temperature and $\mathrm{pH}$.

\section{METHOD}

\section{A. Fungus Preparation}

Gliomastix sp. T3.7 was from lab collection of Microbiology and Biotechnology laboratory, ITS Surabaya. The fungus was recultured on PDA medium at $28^{0} \mathrm{C}$ for 5 days until the fungus was overgrowth. The fungus culture was then cut in plugs with $10 \mathrm{~mm}$ diameter and picked up from PDA medium. Each fungus plugs was further treated as below.

\section{B. Ligninolytic Enzyme Production}

Organic wastes were rice straw, corncobs and sawdust from an agriculture area in Ponorogo and sugarcane baggase from Kenjeran, Surabaya. They were cut in to very small pieces of about 40 mesh size. The particular organic waste powder was then dried out at $75^{\circ} \mathrm{C}$ for 2 days until it reached a constant dry weight.

A production medium consisted of 5 gr each organic waste powders and $25 \mathrm{ml}$ distilled water were put into $250 \mathrm{ml}$ Erlenmeyer flask and autoclaved at $121^{\circ} \mathrm{C}, 1.5$ atm pressure for about 15 minutes. Before autoclaving, $\mathrm{pH}$ of each production medium was adjusted with a serial $\mathrm{pH}$ value from 4 to 6 . Afterward each adjusted $\mathrm{pH}$ medium of each particular organic waste powder was then inoculated with 2 fungus plugs and incubated for 5 days. The incubations were performed in a different temperature ranges from $25^{\circ}$ to $35^{\circ} \mathrm{C}$.

\section{Enzyme Extraction}

The produced ligninolytic enzymes were harvested in a crude method. A neutral phosphate buffer ( $\mathrm{pH} \mathrm{7)}$ was used for extracting the crude enzyme with ratio production culture:buffer was 1:2 (w/v). After pouring the buffer into the production culture, the culture was homogenized with a gentle hand shaking and centrifuged at 5,000 rpm for $20 \mathrm{~min}$ on $0-4^{0} \mathrm{C}$. The centrifugation was repeated until clean filtrate was obtained.

LiP (1.11.1.14) activity was determined by monitoring of $\lambda 310 \mathrm{~nm}$ change. Lignin peroxidase activity was determined spectrophotometrically according to [13]. The reaction mixture contained $0.5 \mathrm{M}$ sodium acetate (pH 3.0), $8 \mathrm{mM}$ veratryl alcohol, $0.2 \mathrm{ml}$ enzyme filtrate and $0.45 \mathrm{ml}$ aquades, in a final volume of $1 \mathrm{ml}$. The reaction was starting by adding $5 \mathrm{mM} \mathrm{H} 2 \mathrm{O} 2$ [1 and 14]. One unit (U) was defined as $1 \mathrm{nmol}$ of veratryl alcohol oxidized in 1 minute and the activities were reported as $\mathrm{U} / \mathrm{ml}$.

MnP (1.11.1.13) activities was determined by monitoring the oxidation of guaiacol spectrophotometrically at $\lambda 465 \mathrm{~nm}$ [15]. The reaction mixture contained $50 \mathrm{mM}$ sodium Na-lactate (pH 4,5), 4 $\mathrm{mM}$ Guaiacol, $0.2 \mathrm{ml}$ enzyme filtrate, $1 \mathrm{mM} \mathrm{MnSO}_{4}$ and $0.3 \mathrm{ml}$ aquades, in a final volume of $1 \mathrm{ml}$. One unit of activity was defined as $1 \mathrm{nmol} / \mathrm{l}$ of $\mathrm{Mn} 2+$ oxidized per minute. Lignocellulolytic enzyme activity (U) was defined as the amount of enzyme needed to oxidize $1 \mu \mathrm{M}$ of substrate per minute.

\section{RESULT AND DISCUSSION}

Activity of ligninolytic enzymes was measured after 5 days inoculation. For the full growth and adaptation onto a solid substrate, the fungus requires this time. Since the fungus mycelium has grown over the organic lignocellulosic waste, it caused nitrogen depletion on medium and changed the metabolic system into a ligninolytic mechanism. Nitrogen depletion was a trigger for initiating a ligninolytic system [11 and 16]. This study was using fungus Gliomastix sp. T3.7 as our previous work [17] clearly showed that it was able to degrade lignin by performing a clear zone with a diameter of $1.4 \mathrm{~cm}$. It was greater than other fungi collection in the Microbiology and Biotechnology Laboratory, ITS.

The effect of $\mathrm{pH}$ on ligninolytic enzymes activity was shown in Table 1-3. The highest activity of Laccase and $\mathrm{MnP}$ was about $1.8 \mathrm{U} / \mathrm{ml}$ and $1 \mathrm{U} / \mathrm{ml}$ on a sugarcane bagasse waste, respectively, while LiP activity was highest $8,088 \mathrm{U} / \mathrm{ml}$ in corn cobs waste. For further optimization studies on bioprocess parameters, sugarcane bagasse and corn cobs were taken as the best organic lignocellulosic waste for maximum ligninolytic enzymes activity of Gliomastix sp. T3.7.

Bagasse and and its extract also can serve as efficient inducers of laccase and MnP activies in Pleurotus ostreatus [18]. Although the identification of possible inducers compounds in the bagasse or its extract was not undertaken, the presence of several compounds such as p-hydroxybenzoic acid, transcinamic acid, transferulic acid, syringaldehyde, vanilin has been reported in bagasse [18 and 19].

Sugarcane bagasse proved to be the best laccase inducer of Phlebia radiata among the various supplements added to different media [20]. Sugarcane bagasse has been reported to be a better substrate for laccase production by Flavodon flavus also [21].

Many fungi secrete higher amount of ligninolytic enzymes in the medium in presence of inducers. Many chemical inducers like xylidine, veratryl alcohol, vanilic acid, veratraldehyde, 3,4-dimethoxycinnamic acid, and 3,4,5-trimethoxy cinnamic acid have been used for induction of ligninolytic enzymes of white rot fungi and the others. However, most of these substances are harmful or expensive. Recently investigations have focused on the use of natural substrates and agricultural wastes for achieving this objective because of their easy accessibility and low cost [18].

The effect of $\mathrm{pH}$ on activity of ligninolytic enzymes was shown in Table 1-3. The activity of Laccase was highest $(1,8 \mathrm{U} / \mathrm{ml})$ at $\mathrm{pH} 5$, as $\mathrm{MnP}$ was highest $(0,9$ $\mathrm{U} / \mathrm{ml}$ ) at $\mathrm{pH} 4$ and LiP was at $\mathrm{pH} 6$ with activity of 8,1 $\mathrm{U} / \mathrm{ml}$. For further optimization studies on bioprocess parameters, $\mathrm{pH}$ value of 4 to 6 were taken as optimum 
for maximum ligninolytic enzymes activity of Gliomastix sp. T3.7.

The intact enzyme contains both of positive and negative charged group at any given $\mathrm{pH}$. Such ionizable groups are often apparently part of the active site. A pH variation in medium may resulted a change of ionic forms of the active sites and activity of the enzymes, and hence the reactions rate. Changes in $\mathrm{pH}$ may also alter the three-dimensional shape of the enzymes [22-25]. For these reasons, enzymes are very active over a certain $\mathrm{pH}$ range [25].

The effect of temperature on ligninolytic enzymes activity was shown in Table 1-3. The highest activity of Laccase was $1.8 \mathrm{U} / \mathrm{ml}$ at $35^{\circ} \mathrm{C}$. MnP was $1 \mathrm{U} / \mathrm{ml}$ at $25^{\circ}$ $\mathrm{C}$ and $\mathrm{LiP}$ was $8.1 \mathrm{U} / \mathrm{ml}$ at $35^{\circ} \mathrm{C}$. For further optimization studies on bioprocess parameters, temperature of 25 and $35^{\circ} \mathrm{C}$ was taken as optimum temperature for ligninolytic enzymes activity of Gliomastix sp. T3.7. For many enzymes, denaturations of proteins begin to occur at $45^{\circ}$ to $50^{\circ} \mathrm{C}$ temperatures. Sensitivity of a protein to denature at elevated temperatures can be varying widely with medium $\mathrm{pH}$, and the influence of various temperature-pH combinations may differ tremendously from enzyme to enzyme [22-25].

Each fungus has unique optimum, minimum and maximum growth temperature; below the optimum growth depresses the rate of metabolism of cells, as well as above the optimal decreases the growth and even death may occur. At higher temperatures (beyond $40^{\circ} \mathrm{C}$ ), a death rate exceeds the growth rate, which causes a net decrease in the concentration of viable fungal cells as well as enzyme activities.

Lignin degradation is a complicated process. The enzymes system for lignolysis of specific culture depended on the strain, substrate, and environment conditions. Laccase might plays the central role in the lignolysis for one strain or culture, while for others, MnP or LiP, even laccase-MnP or laccase-MnP-LiP might be responsible for the same process [26]. Gliomastix sp. T3.7 was a potential microorganism which produced ligninolityc enzyme such as laccase, LiP an MnP. This study was needed to be investigated further until to reach the main goal of a using Gliomastix sp.for industrial pulp and paper as extracellular ligninolytic enzymes source.

\section{CONCLUSION}

a. Gliomastix sp. T3.7 has potential as a ligninolityc enzymes producing fungus, such as laccase, LiP an $\mathrm{MnP}$.

b. Sugarcane bagasse waste was the best inducers for laccase and MnP, whereas corncob was for LiP.

c. Temperature of 25 and $35^{\circ} \mathrm{C}$ and $\mathrm{pH}$ value of 4 to 6 were optimum conditions for ligninolytic enzymes activity produced by Gliomastix sp. T3.7.

\section{ACKNOWLEDGMENTS}

The authors would like to express their respectful thanks to the Biology Department of the ITS, LPPM of ITS, DP2M, due to their executive financial supports and to our students Ima Mufidatul Ilmi who helped us for conducting the experiments.

\section{REFERENCES}

[1] S. R. Couto and M. A. Sanromán, "Application of Solid-State Fermentation to ligninolytic Enzyme Production," Biochemical Engineering Journal, vol. 22, no. 3, p. 211-219, 2005.

[2] W.-H. Chen, Y.-J. Tu and H.-K. Sheen, "Disruption of Sugarcane Bagasse Lignocellulosic Structure by Means of Dilute Sulfuric Acid Pretreatment with Microwave-Assisted Heating," Applied Energy, vol. 88, no. 8, p. 2726-2734, 2011.

[3] B. Monties and K. Fukushima, "Occurrence, Function, and Biosynthesis of Lignins," in Biopolymers, Volume 1, Lignin, Humic Substances and Coal, Weinheim, Germany, Wiley- VCH, 2001, p. 1-64.

[4] G. Brunow, "Methods to reveal the structure of lignin," in Biopolymers, Vol. 1-Lignin, Humic Substances and Coal, Weinheim, Germany, Wiley-VCH, 2001, p. 89- 116.

[5] M. Hofrichter, "Review: Lignin Conversion by Manganese Peroxidase (MnP)," Enzyme and Microbial Technology, vol. 30, no. 4, p. 454-466, 2002.

[6] M. Hofrichter, "Review: Lignin Conversion by Manganese Peroxidase (MnP)," Enzyme and Microbial Technology, vol. 30, no. 4, p. 454-466, 2002.

[7] T. K. Kirk and H. M. Chang, Biotechnology in Pulp and Paper Manufacture, New York, USA: Butterworth Hanimenam Publication, 1980

[8] T. K. Kirk and K. E. Eriksson, "Lignin Biodegradation with white-rot fungi," in Comprehensive Biotechnology Vol. 4, Oxford, JA Pergamon Press Ltd, 1981, pp. 271-294.

[9] M. W. Plat, Y. Hadar, Y. Henis and I. Chet, "Fungal Activities Involved in Lignocellulosic Degradation by Pleurotus sp.," Applied Microbiology and Biotechnology, vol. 20, no. 2, pp. 150$154,1983$.

[10] B. R. M. Vyas, J. Volc and V. Šašek, "Ligninolytic Enzymes of Selected White-Rot Fungi Cultivated on Wheat Straw," Folia Microbiologica, vol. 39, no. 3, pp. 235- 240, 1994.

[11] S. M. Hossain and N. Anantharaman, "Activity Enhancement of Ligninolytic Enzymes of Trametes Versicolor with Bagasse Powder," African Journal of Biotechnology, vol. 5, no. 1, pp. 189-194, 2006.

[12] H. Widiastuti, Suharyanto, A. Wulaningtyas and Sutamihardja, "Activity of Ligninolytic Enzymes during Growth and Fruiting Body Development of White Rot Fungi Omphalina sp. and Pleurotus Ostreatus," HAYATI Journal of Biosciences, vol. 15, no. 4, pp. 140-144, 2008.

[13] R. Bourbonnais and M. Paice, "Oxidation of Non-Phenolic Substrates: An Expanded Role of Laccases in Lignin Biodegration," FEBS letter, vol. 267, no. 1, pp. 99-102, 1990.

[14] M. Tien and T. K. Kirk, "Lignin Peroxidase of Phanerochaete Chrysosporium," Methods in Enzymology, vol. 161, p. 238-249, 1988.

[15] R. I. Syafrizal, Aktifitas enzim Ligninolitik Fungi Pelapuk Putih Omphalina sp. dan Pleurotus Ostreatus pada Limbah Lignoselulosa, Bogor: Program Studi Biokimia, FMIPA, Institut Pertanian Bogor, 2007.

[16] A. Hattaka, "Modifying Enzymes from Selected White-Rot Fungi: Production and Role in Lignin Degradation," FEMS Microbiology Reviews, vol. 13, no. 2-3, pp. 125-135, 1994.

[17] E. E. J. Kaal, J. A. Field and T. W. Joyce, "Increasing Ligninolytic Enzyme Activities in Several White-Rot Basidiomycetes by Nitrogen -Sufficient Media," Bioresource Technology, vol. 53, no. 2, pp. 133-139, 1995.

[18] Y. M. Rohmah, "Studi Potensi Isolat Kapang Tanah dari Wonorejo Surabaya dalam Mendegradasi Lignin," Biologi ITS, Surabaya, 2012.

[19] S. Sen, P. P. Singh, V. S. Rathore and B. M. J. Pereira "Sugarcane Bagasse Improves The Activity of Ligninolytic Enzymes and Decolourization of Dyes by The White-Rot Fungus Pleurotus Ostreatus," Journal of Scientific \& Industrial Research, vol. 63, no. 9, pp. 739-746, 2004.

[20] H. M. Cunha and F. T. Silva, "Identification of Low Molecular Weight Aromatic Compounds Present in The Hydrolysate Obtained From Sugarcane Baggase Pretreated by Steam Explosion," in 6th Brazilian Symposium Chemistry of Lignin and Other Wood Components, Guaratingueta, Sao paulo, Brazil, 2001 . 
[21] D. S. Arora and P. K. Gill, "Effects of Various Media and Supplements on Laccase Production by some White Rot Fungi," Bioresource Technology, vol. 77, no. 1, pp. 89-91, 2001.

[22] C. Raghukumar, T. M. D'souza, R. G. Thorn and C. A. Reddy, "Lignin-Modifying Enzymes of Flavodon Flavus, Basidiomycete Isolated from A Costal Marine Environment," Applied and Environmental Microbiology, vol. 65, no. 5, pp. 2103-2111, 1999.

[23] J. E. Bailey and D. F. Ollis, Biochemical Engineering Fundamentals, New York: McGraw-Hill Inc, 1981.
[24] M. L. Shulter and F. Kargi, Bioprocess engineering : Basic concept, New Delhi: Parentice-Hall of India Pvt Ltd, 2000.

[25] M. J. Pelezar, E. C. S. Chan and N. R. Kring, Microbiology, 5th edition, New Delhi: Tata McGraw-Hill Publishing Co Ltd, 2004.

[26] F. Sun, J. Li, Y. Yuan, Z. Y. Yan and X. F. Liu, "Effect of Biological Pretreatment with Trametes Hirsuta yj9 on Enzymatic Hydrolysis of Corn Stover," International Biodeterioration \& Biodegradation, vol. 65, no. 7, pp. 931-938, 2011.

TABLE 1.

LACCASE ENZYME ACTIVITY ON VARIETY PH, TEMPERATURE AND ORGANIC LIGNOCELLULOSIC WASTE

\begin{tabular}{|c|c|c|c|}
\hline \multicolumn{4}{|c|}{ Laccase enzyme activity (U/ml) } \\
\hline Temperature $\left({ }^{0} \mathrm{C}\right)$ & $\mathrm{pH} 4$ & $\mathrm{pH} 5$ & pH 6 \\
\hline \multicolumn{4}{|c|}{ Rice straw } \\
\hline 25 & $0,734^{\mathrm{c}}$ & $0,049^{\mathrm{a}}$ & $0,485^{\mathrm{bc}}$ \\
\hline 30 & $1,403^{\mathrm{d}}$ & ND & $0,204^{\mathrm{a}}$ \\
\hline 35 & $0,113^{\mathrm{a}}$ & $0,09^{\mathrm{a}}$ & $1,449^{\mathrm{e}}$ \\
\hline \multicolumn{4}{|c|}{ Corncobs } \\
\hline 25 & $0,369^{a b}$ & $0,296^{\mathrm{ab}}$ & $0,35^{\mathrm{ab}}$ \\
\hline 30 & $0,186^{\mathrm{a}}$ & $0,283^{a b}$ & $1,069^{d}$ \\
\hline 35 & $0,001^{\mathrm{a}}$ & $0,002^{\mathrm{a}}$ & $0,448^{\mathrm{b}}$ \\
\hline \multicolumn{4}{|c|}{ Sugarcane bagasse } \\
\hline 25 & $0,551^{\mathrm{bc}}$ & ND & $1,723^{\mathrm{e}}$ \\
\hline 30 & $1,117^{\mathrm{d}}$ & $0,269^{\mathrm{ab}}$ & $0,468^{b c}$ \\
\hline 35 & $1,736^{\mathrm{e}}$ & $1,765^{\mathrm{e} *}$ & $0,863^{\mathrm{c}}$ \\
\hline \multicolumn{4}{|c|}{ Sawdust } \\
\hline 25 & $0,221^{\mathrm{ab}}$ & $0,589^{\mathrm{bc}}$ & $0,279^{a b}$ \\
\hline 30 & $1,053^{\mathrm{d}}$ & $1,456^{\mathrm{e}}$ & $0,621^{b c}$ \\
\hline 35 & $0,981^{\mathrm{d}}$ & $0,718^{\mathrm{c}}$ & $0,349^{a b}$ \\
\hline
\end{tabular}

ND : Not Detected. The number followed with the same letter on one group showed insignificantly different with Duncan's test $(\mathrm{P}<0,05)$

TABLE 2.

LIP ENZYME ACTIVITY ON VARIETY PH, TEMPERATURE

AND ORGANIC LIGNOCELLULOSIC WASTE

LiP enzyme activity (U/ml)

\begin{tabular}{|c|c|c|c|}
\hline Temperature $\left({ }^{\circ} \mathrm{C}\right)$ & $\mathrm{pH} 4$ & $\mathrm{pH} 5$ & $\mathrm{pH} 6$ \\
\hline & \multicolumn{3}{|c|}{ Ricestraw } \\
\hline 25 & ND & 3,405 & 0,556 \\
\hline 30 & ND & 4,253 & 1,416 \\
\hline \multirow[t]{2}{*}{35} & 0,018 & 4,498 & 0,735 \\
\hline & \multicolumn{3}{|c|}{ Corncobs } \\
\hline 25 & 0,036 & 0,233 & 0,102 \\
\hline 30 & 1,022 & 0,048 & 0,066 \\
\hline \multirow[t]{2}{*}{35} & 0,018 & 0,006 & $8,088^{*}$ \\
\hline & \multicolumn{3}{|c|}{ Sugarcane bagasse } \\
\hline 25 & 0,066 & 0,081 & ND \\
\hline 30 & 0,185 & 0,269 & 0,081 \\
\hline \multirow[t]{2}{*}{35} & 0,179 & 0,09 & 0,723 \\
\hline & \multicolumn{3}{|c|}{ Sawdust } \\
\hline
\end{tabular}


IPTEK, The Journal for Technology and Science, Vol. 26, No. 1, April 2015

\begin{tabular}{rlll}
\hline $\mathbf{2 5}$ & 0,096 & 0,197 & 0,281 \\
$\mathbf{3 0}$ & 0,173 & 0,257 & 0,281 \\
$\mathbf{3 5}$ & 0,245 & 0,185 & 0,293 \\
\hline \hline
\end{tabular}

TABLE 3.

MNP ENZYME ACTIVITY ON VARIETY PH, TEMPERATURE AND ORGANIC LIGNOCELLULOSIC WASTE

MnP enzyme activity $(\mathrm{U} / \mathrm{ml})$

\begin{tabular}{|c|c|c|c|}
\hline \multicolumn{4}{|c|}{ MnP enzyme activity (U/ml) } \\
\hline Temperature $\left({ }^{\circ} \mathrm{C}\right)$ & $\mathrm{pH} 4$ & $\mathrm{pH} 5$ & $\mathrm{pH} 6$ \\
\hline \multicolumn{4}{|c|}{ Rice straw } \\
\hline 25 & ND & ND & $0,028^{\mathrm{a}}$ \\
\hline 30 & ND & $0,199^{\mathrm{ab}}$ & $0,032^{\mathrm{a}}$ \\
\hline 35 & ND & $0,138^{a b}$ & $0,657^{\mathrm{d}}$ \\
\hline \multicolumn{4}{|c|}{ Corn cobs } \\
\hline 25 & ND & $0,032^{\mathrm{a}}$ & $0,859^{d}$ \\
\hline 30 & ND & ND & $0,009^{\mathrm{a}}$ \\
\hline 35 & ND & ND & ND \\
\hline \multicolumn{4}{|c|}{ Sugarcane baggase } \\
\hline 25 & $0,964^{\mathrm{e} *}$ & $0,764^{\mathrm{d}}$ & $0,464^{\mathrm{c}}$ \\
\hline 30 & $0,147^{\mathrm{ab}}$ & $0,399^{\mathrm{c}}$ & $0,055^{\mathrm{ab}}$ \\
\hline 35 & $0,014^{\mathrm{a}}$ & $0,225^{\mathrm{ab}}$ & $0,652^{d}$ \\
\hline \multicolumn{4}{|c|}{ Sawdust } \\
\hline 25 & ND & ND & $0,073^{a b}$ \\
\hline 30 & $0,11^{\mathrm{ab}}$ & $0,523^{c}$ & $0,023^{\mathrm{a}}$ \\
\hline 35 & $0,285^{\mathrm{bc}}$ & $0,005^{\mathrm{a}}$ & $0,046^{\mathrm{ab}}$ \\
\hline
\end{tabular}

ND : Not Detected. The number followed with the same letter on one group showed insignificantly different with Duncan's test $(\mathrm{P}<0,05)$ 